\title{
ORCHARD ORIOLES AT OAK LAKE, MANITOBA
}

by David R. M. Hatch, Oak Lake

The first Orchard Oriole (Icterus spurius) to be recorded at Oak Lake, Manitoba, was in 1923 ; it was identified by Mr. Herman Battersby. It was 39 years before another Orchard Oriole was reported at Oak Lake. After this long period of absence at least three were observed in the Oak Lake area in 1962. On June 9, 1962, a male in first year or sub-adult plumage and a female were observed by Mr. Battersby and myself at his home six miles south of the town of Oak Lake. These two birds remained together constantly and appeared to be paired. The male sang frequently throughout the afternoon and evening that it was under observation. Both birds were exceedingly wary, making it difficult to observe them in the dense foliage. The female was observed only on the rarest occasions and then only in fleeting glimpses. Despite the fact that the male sang from the uppermost branches of maples and almost exclusively from within clumps of leaves, some excellent views were obtained.

This male was generally greenish above and very pale yellow below. From the base of its bill downward, its throat was black. The song of this species is unmistakable and once heard it will never be forgotten. These two birds were seen regularly at the Battersby residence from June 9 to 18 inclusive, but were not seen in the area after June 18 . When first seen the male sang very frequently, but he seemed to sing less and less each day and was not heard at all after June 18. Without the song it was difficult to locate the bird, so the possibility does exist that the pair could have lingered in the area longer than recorded. We hunted diligently for a nest but were unable to find any sign of one.

Much to my surprise, on June 17, 1962, a fully plumaged adult male Orchard Oriole appeared at the near- by farm grove of my parents, Mr. and Mrs. Lloyd M. Hatch. The difference in plumage between male Orchard Oriole and Baltimore Oriole is striking. The orange of the rump and breast of the Baltimore is replaced by a deep rusty colour in the Orchard. The tail of the Orchard is pure black, while that of the Baltimore has a good deal of orange. The fully adult breeding male Orchard is an all dark oriole. This particular one was not as wary as the two observed at the Battersby residence. It spent all of June 17, 18 and 19 in the grove before departing just one day after the two disappeared from Mr. Battersby's place. My parents' home and Mr. Battersby's residence are only onehalf mile apart and are separated by open prairie. It would be interesting to know if these three birds represented a movement into the area in 1962. The male at the Hatch residence acted very much as if he was hunting a mate because he sang every few minutes during the daytime on all three days he was present. No other Orchard Orioles were seen in 1962 in the Oak Lake area.

On June 16, 1963, I had many excellent opportunities to observe a fully plumaged adult male Orchard Oriole at my parents' home. This bird remained for four days, being last seen on June 19. On this occasion, it acted very similarly to the one seen at the Hatch residence in 1962. No other reports of Orchard Orioles were received in 1963 and it appears that this was an isolated record.

On June 14, 1964, an adult male in full plumage again put in an appearance at the Hatch residence but was seen on just the one day. This was the only Orchard Oriole seen in the area in 1964. The fact that a male Orchard Oriole was seen for three consecutive years at the Hatch residence, and at almost the 
same time of the year on all three occasions, is most interesting.

These Oak Lake records of the Orchard Oriole caused me to review the status of the species in Manitoba. After studying all available information, I concluded that the species is a casual visitor to this province. The following Manitoba records of this species are all that I have been able to locate.

Mr. Harold Mossop in "Chickadee Notes" No. 281 reviewed the provincial records as follows: "It has been seen in Manitoba several times: at East Bay in 1921 by E. Robinson; at Oak Lake in 1923 by H. Battersby; at Thornhill in 1923-4-7 and 8 by $H$. Buchanan and at Winnipeg in 1929 by F. Rogers. Also in 1929, it was found nesting at Cypress River by Mrs. E. J. McMillan." A further note on Orchard Orioles in "Chickadee Notes" No. 389 states that in 1929 there was a small movement into the Winnipeg area as "two separate records in Winnipeg by Fred Rogers and C. E. Keighley, also one picked up dead in North Kildonan by $A$. Moun" were reported. This specimen was given by Mr. Moun to the late Mr. A. B. Gresham. It is now in the Manitoba Museum and is dated May 30, 1929.

In The Birds of the Lake St. Martin Area (T. M. Shortt and S. Waller, 1937, Contr. Royal Museum of Zoology, No. 10, Ontario), the following note concerning this species is made: "A male in high breeding plumage, taken on June 6, 1932, constitutes the only record and seems to be the most northerly occurrence of the species. It should not be regarded, perhaps, as accidental, since the species has been found on several occasions in Southern Manitoba since 1929. These occurrences have been recorded by Cartwright (1931). It may best be termed a northern marginal occurrence." This specimen is now in the Royal Ontario Museum.

On May 29, 1960, Mr. Fred Coutts observed a full plumage adult male Orchard Oriole in Brookside Ceme- tery in the northwest section of Greater Winnipeg. On June 5, this bird was "seen and heard several times" by many local birders. This oriole spent its time in one clump of trees in the cemetery and as if it had established territory, it never was seen in any other part of the cemetery. It was last noted in the area on June 19. The following year, 1961, Mr. Coutts again saw an adult male in Brookside Cemetery on June 4 and 5. It could not be located after this date. This bird had its complete adult plumage and there is a very strong possibility that it was the same bird as the one seen in 1960 .

A review of these Manitoba records shows they are concentrated in two periods of years, 1921 to 1932 and 1960 to 1964 . The number of birds involved has seldom been more than one or two, yet they have been found from Winnipeg and East Bay in the east to Oak Lake in the west. In the south, they have been reported from Cypress River and Thornhill, while there is an isolated record for Lake St. Martin in northern Manitoba.

\section{WINTER BIRD SURVEY}

by J. B. Gollop, Saskatoon

Anyone interested in conducting a periodic winter bird survey, with emphasis on Snowy Owls and Gray (Hungarian) Partridge, is asked to contact me at 2202 York, Saskatoon. A brief description of the method and the results of one winter's work in the Saskatoon district was given in the March 1965 Blue Jay. I will supply more details so that observations may be made in a uniform way with results from one area to another being comparable.

Fewer miles were driven around Saskatoon in the winter of 1964-65, but the difference was not enough to account for only 24 Snowy Owl observations as compared to 154 in 196364 . The largest number of owls on one day this past winter was 4 ; the previous winter 12,15 and 19 were the highest daily counts. The first Snowy Owl reported this fall in this area was at Goose Lake on October 24. 